\title{
Use of Rh (III)-Heteropolymolybdate as Potential Catalysts for the Removal of Nitrates in Human Drinking Water: Synthesis, Characterisation and Catalytic Performance
}

\author{
María A. Jaworski $(\mathbb{D} \cdot$ Guillermo R. Bertolini • \\ Carmen I. Cabello • Guillermo J. Siri • \\ Mónica L. Casella
}

Received: 2 October 2017 / Accepted: 17 August 2018

(C) Springer Nature Switzerland AG 2018

\begin{abstract}
The investigation and development of technologies to remediate water contaminated with $\mathrm{NO}_{3}{ }^{-}$are constantly increasing. An economically and potentially effective alternative is based on the catalytic hydrogenation of $\mathrm{NO}_{3}{ }^{-}$to $\mathrm{N}_{2}$. With this objective, bimetallic $\mathrm{RhMo}_{6}$ catalysts based on Anderson-type heteropolyanion $\left(\mathrm{RhMo}_{6} \mathrm{O}_{24} \mathrm{H}_{6}\right)^{3-}$ were prepared and characteri3ed in order to obtain well-defined bimetallic catalyst. The catalysts were supported on $\mathrm{Al}_{2} \mathrm{O}_{3}$ with different textural properties and on silica. The heteropolyanion-support interaction was analysed by temperature-programmed reduction (TPR) and X-ray photoelectron spectroscopy (XPS). The differences obtained in activity and selectivity to the different products can be assigned to the different interaction between the $\mathrm{RhMo}_{6}$ Anderson phase and the supports. The $\mathrm{RhMo}_{6} / \mathrm{G},\left(\mathrm{G}: \gamma-\mathrm{Al}_{2} \mathrm{O}_{3}\right)$ system showed the best catalytic performance. This catalyst exhibited the lowest reduction
\end{abstract}

M. A. Jaworski $(\bowtie) \cdot$ G. R. Bertolini • C. I. Cabello •

G. J. Siri • M. L. Casella

Centro de Investigación y Desarrollo en Ciencias Aplicadas "Dr. Jorge J. Ronco" (CINDECA), CCT-CONICET La Plata, Universidad Nacional de La Plata and Comisión de Investigaciones Científicas de la Provincia de Buenos Aires (CICPBA), calle $47 \mathrm{~N}^{\circ}$ 257, 1900 La Plata, Argentina e-mail: majaworski@quimica.unlp.edu.ar

M. A. Jaworski · G. J. Siri

PIDCAT-Facultad de Ingeniería (UNLP), 47 N² 257, La Plata, Argentina

C. I. Cabello

Miembro CIC, Comisión de Investigaciones Científicas y

Técnicas, Provincia de Buenos Aires and Facultad de Ingeniería UNLP, La Plata, Argentina temperature of $\mathrm{Rh}$ and Mo in the TPR assay and a $\mathrm{Rh} / \mathrm{Mo}$ surface ratio similar to that of the original phase, as observed by XPS analysis. These studies allowed us to verify a synergic effect between $\mathrm{Rh}$ and Mo, through which Mo reducibility was promoted by the presence of the noble metal. The catalytic activity was favoured by the active sites generated from the Anderson phase. This fact was confirmed by comparing the activity of $\mathrm{RhMo}_{6} / \mathrm{G}$ with that corresponding to a conventional catalyst prepared through successive impregnation of both Rh (III) and Mo (VI) salts.

Keywords Nitrate $\cdot$ Water pollution $\cdot$ Well-defined catalysts $\cdot$ Anderson phase $\cdot$ Hydrogenation $\cdot$ Synergic effect

\section{Introduction}

Traditionally, soils have been fertilised with $\mathrm{NO}_{3}{ }^{-}$to improve agricultural yields. Since the artificial synthesis of ammonia was achieved by the Haber process, it has been possible to produce nitrogen fertilisers, which are currently used in large quantities in agriculture (Haber and Le Rossignol 1910). As a result of this intensive use of fertilisers, $\mathrm{NO}_{3}{ }^{-}$concentration has been constantly increasing in groundwater since 1950 (Costa et al. 2012).

The intake of water containing $\mathrm{NO}_{3}{ }^{-}$has adverse effects on human health, so maximum tolerable levels have been established for $\mathrm{NO}_{3}{ }^{-}$in water for human consumption (45 ppm according to the US Environmental Protection Agency). $\mathrm{NO}_{3}{ }^{-}$is harmful because it is reduced 
to $\mathrm{NO}_{2}{ }^{-}$in the human body and $\mathrm{NO}_{2}{ }^{-}$favours the development of methemoglobinaemia, which is a deficiency of oxygen in blood that can put life in danger, especially for children under 6 months ("blue baby syndrome"). When $\mathrm{NO}_{3}{ }^{-}$is transformed to $\mathrm{NO}_{2}{ }^{-}$in the human body, other reactions can take place. $\mathrm{NO}_{2}{ }^{-}$could react with amine compounds to form the so-called N-nitrosamines (NOC, $\mathrm{N}$-nitroso compound), some of which have proven to be mutagenic and carcinogenic (Citak and Sonmez 2010).

Nitrate is a stable and highly soluble ion with low tendency to co-precipitation and adsorption. These properties make it difficult to be removed from water. The application of technologies to remediate polluted groundwater with $\mathrm{NO}_{3}{ }^{-}$is increasing, particularly in places where alternative water supplies are unavailable. These technologies include ion exchange, reverse osmosis, electro dialysis, photocatalytic reduction, biological methods and catalytic reduction (Ding et al. 2017; Kim et al. 2016).

The best technique to remove $\mathrm{NO}_{3}{ }^{-}$from contaminated groundwater is the one that can convert this anion into $\mathrm{N}_{2}$. Since Vorlop and Tacke (1989) developed the $\mathrm{NO}_{3}{ }^{-}$reduction to $\mathrm{N}_{2}$ using bimetallic catalysts in the presence of a reducing agent, numerous studies have been carried out in order to find the most efficient catalysts for that process. One of the most accepted mechanisms for this reaction establishes that $\mathrm{NO}_{3}{ }^{-}$can only be hydrogenated using bimetallic catalysts if an inert support is used, while $\mathrm{NO}_{2}{ }^{-}$and other reaction intermediates are reduced by monometallic catalysts (Barrabés and Sá 2011). For this reason, the most studied catalytic systems are bimetallic catalysts, composed of a noble metal (Pd, $\mathrm{Pt}, \mathrm{Rh})$ that can easily chemisorb $\mathrm{H}_{2}$ and a second metal, such as $\mathrm{Cu}, \mathrm{Ni}, \mathrm{Fe}, \mathrm{Sn}$ or In (Barrabés and Sá 2011; Bae et al. 2013; Choi et al. 2013). In these catalysts, the bimetallic sites allow the reduction of $\mathrm{NO}_{3}{ }^{-}$to $\mathrm{NO}_{2}{ }^{-}$, which is then reduced to $\mathrm{N}_{2}$ or over-reduced to $\mathrm{NH}_{4}{ }^{+}$on monometallic sites, as shown in the following equations:

$\mathrm{NO}_{3}^{-}+\mathrm{H}_{2} \rightarrow \mathrm{NO}_{2}^{-}+\mathrm{H}_{2} \mathrm{O}$

$2 \mathrm{NO}_{2}^{-}+3 \mathrm{H}_{2} \rightarrow \mathrm{N}_{2}+2 \mathrm{H}_{2} \mathrm{O}+2 \mathrm{OH}^{-}$

$\mathrm{NO}_{2}^{-}+3 \mathrm{H}_{2} \rightarrow \mathrm{NH}_{4}^{+}+2 \mathrm{OH}^{-}$

Different studies reveal that the activity and selectivity to $\mathrm{N}_{2}$ in $\mathrm{NO}_{3}{ }^{-}$removal reaction depends on the interaction between the metals forming the active phase (a fact that can be controlled by the preparation method), the nature of the promoter, the metal/promoter ratio and the operating conditions (Soares et al. 2010).

In this sense, numerous recent studies have focused mainly on the development of new catalysts with a defined chemical composition and an orderly distribution of the elements of the active phase that are active in the reduction of nitrate. The methodologies tested included the preparation and use of $\mathrm{PtSn} / \gamma-\mathrm{Al}_{2} \mathrm{O}_{3}$ bimetallic catalysts prepared by Surface Organometallic Chemistry on Metals techniques (Jaworski et al. 2013), preparation of $\mathrm{Pd}$ and In catalysts by sequential electroless plating on activated carbon felts (Zoppas et al. 2016) and more recently, $\mathrm{PdAg} / \mathrm{SiO}_{2}-\mathrm{NH}_{2}$ catalyst were developed by a controlled surface reaction to load $\mathrm{Ag}$ and create $\mathrm{PdAg}$ alloy nanoparticles on $\mathrm{NH}_{2}$ surface-modified $\mathrm{SiO}_{2}$ catalyst support $\left(\mathrm{SiO}_{2}-\mathrm{NH}_{2}\right)$ (Ding et al. 2017).

The heteropolyoxomolybdates forming Anderson phases of $\mathrm{Co}$, $\mathrm{Ni}$ or $\mathrm{Rh}$ have emerged as interesting precursors in heterogeneous catalysts in various processes and have begun to replace different conventional oxidic precursors improving the efficiency and the environmental conditions of various catalytic processes (Mizuno and Misono 1998; Pettiti et al. 2001). The planar structure of the heteropolyanion and its redox and acidity properties are relevant factors in the heteropolyanion-support interaction process, which produces an active surface with an ordered distribution and uniform deposit of metallic elements, thus favouring the synergistic effect between the transition metal and Mo. In Fig. 1, the polyhedral structure of $\mathrm{Rh}$ (III)-heteropolyoxomolybdate of formula

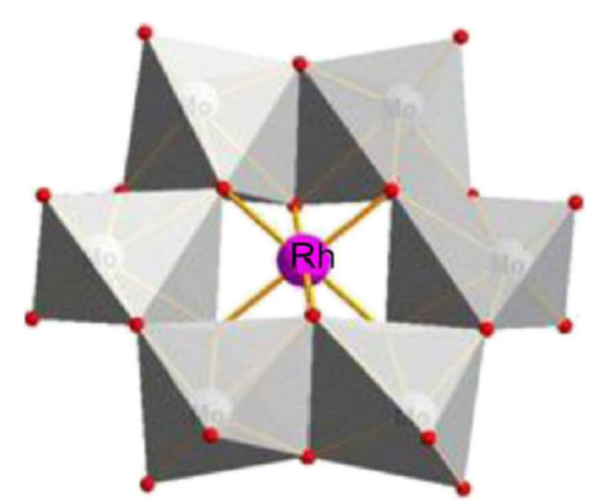

Fig. 1 Representation of the structure corresponding to the planar-type Anderson phase Rh (III) hexamolybdate $\left[\mathrm{RhMo}_{6} \mathrm{O}_{24} \mathrm{H}_{6}\right]^{3-}$ 
$\left[\mathrm{RhMo}_{6} \mathrm{O}_{24} \mathrm{H}_{6}\right]^{3-}$ is shown. Its configuration $\left(\mathrm{D}_{3 \mathrm{~d}}\right.$ planar symmetry) consists of a central $\mathrm{Rh}$ (III) heteroatom surrounded by six octahedral $\mathrm{MoO}_{6}$ groups. Each $\mathrm{MoO}_{6}$ shares an edge with each of its two neighbouring $\mathrm{MoO}_{6}$ and another edge with the $\mathrm{Rh}$ $(\mathrm{OH})_{6}$ octahedron (Cabello et al. 2000).

Recently, bimetallic RhMo precursors generated from heteropolyoxomolybdates of the Anderson-type structure with formula $\left(\mathrm{NH}_{4}\right)_{3}\left[\mathrm{RhMo}_{6} \mathrm{O}_{24} \mathrm{H}_{6}\right] \cdot 7 \mathrm{H}_{2} \mathrm{O}$ supported on $\gamma-\mathrm{Al}_{2} \mathrm{O}_{3}$ or modified clays have been successfully employed in the hydrogenation of cinnamaldehyde to hydrocinnamaldehyde (Bertolini et al. 2013, 2016).

Regarding the limited publications about the application of heteropolycompounds in catalytic hydrogenation in aqueous solutions, this work aims to study the catalytic hydrogenation of $\mathrm{NO}_{3}{ }^{-}$in water with bimetallic RhMo catalysts prepared using a Rh (III) and Mo (VI) Anderson phase. The performance of the catalysts is a combination of the nature and structure of the active phase and the chemical and textural characteristics of the support so the discussion is also focused on the nature of the supports employed.

\section{Experimental}

\subsection{Preparation of the Supports}

An alumina support (B) was prepared in our laboratory starting from the precursor "gibbsite" $\left(\mathrm{Al}(\mathrm{OH})_{3}\right)$. Different calcination temperatures (in the range 480$900{ }^{\circ} \mathrm{C}$ ) were tested in order to obtain a support with suitable textural properties.

To analyse the effect of the support, three other supports were selected: two commercial aluminium oxides of different origin and another one based on silica. The alumina supports were a commercial $\gamma-\mathrm{Al}_{2} \mathrm{O}_{3}$ (Esferalite) and one $\alpha-\mathrm{Al}_{2} \mathrm{O}_{3}$, named $\mathrm{G}$ and $\mathrm{A}$, respectively.

In order to condition the silica-based support, the commercial silica (Degussa Aerosil 200) was submitted to a procedure published by Dalmon and Martin (1980). Approximately, $20 \mathrm{~g}$ of the material was treated with $100 \mathrm{~mL}$ of aqueous $\mathrm{NH}_{4}(\mathrm{OH})$, reaching a $\mathrm{pH}$ of 10.6 , to improve its hydrophilic and textural properties. The system was kept at $25{ }^{\circ} \mathrm{C}$ in a thermostatic bath for $30 \mathrm{~min}$. The solid was then separated from the solution by filtration and dried in an oven for $24 \mathrm{~h}$ at $105{ }^{\circ} \mathrm{C}$.
After this treatment, the surface of the support is composed of "silanol" groups $\mathrm{SiO}_{2}-\mathrm{OH}$, increasing its specific surface area, pore volume and pore diameter. This support was designated as $\mathrm{S}$.

\subsection{Anderson Phase Preparation}

The procedure to obtain the Anderson phase $\left(\mathrm{NH}_{4}\right)_{3}\left[\mathrm{RhMo}_{6} \mathrm{O}_{24} \mathrm{H}_{6}\right] .7 \mathrm{H}_{2} \mathrm{O}$ (hereafter, $\mathrm{RhMo}_{6}$ ) was as follows: $20 \mathrm{~mL}$ of a solution containing $0.70 \mathrm{~g}$ of $\left(\mathrm{NH}_{4}\right)_{6}\left[\mathrm{Mo}_{7} \mathrm{O}_{24}\right] \cdot 4 \mathrm{H}_{2} \mathrm{O}$ (hereafter, HMA), previously heated to $T<80{ }^{\circ} \mathrm{C}$ to facilitate its dissolution, and $10 \mathrm{~mL}$ of an aqueous solution containing the stoichiometric amount of $\mathrm{RhCl}_{3} \cdot \mathrm{H}_{2} \mathrm{O}$ were mixed. The $\mathrm{pH}$ was adjusted to 5-6 with an $\mathrm{NH}_{4} \mathrm{Cl}$ solution. The system was kept at room temperature for several days until the appearance of the corresponding precipitate. Then, the solid was filtered, washed and dried in an oven at $80^{\circ} \mathrm{C}$.

\subsection{Catalyst Preparation}

Starting from the Anderson phase, the following catalysts were prepared: $\mathrm{RhMo}_{6} / \mathrm{B}, \mathrm{RhMo}_{6} / \mathrm{G}, \mathrm{RhMo}_{6} / \mathrm{A}$ and $\mathrm{RhMo}_{6} / \mathrm{S}$ using the equilibrium-adsorption method. A RhMo ${ }_{6}$ aqueous solution having a Mo concentration of $10 \mathrm{mg} / \mathrm{mL}$ was employed in order to obtain catalysts with $6 \mathrm{wt} \%$ Mo and $1 \mathrm{wt} \%$ Rh adsorbed on the supports. After the impregnation process, the catalyst was separated from the solution by centrifugation and then dried in an oven at $80^{\circ} \mathrm{C}$.

In addition, some reference catalysts were prepared. (i) A conventional bimetallic catalyst (designated as $\mathrm{RhMo} / \mathrm{G}$ ) prepared by successive impregnation, using HMA and $\mathrm{RhCl}_{3} \cdot 6 \mathrm{H}_{2} \mathrm{O}$. Appropriate amounts of each salt were dissolved in water in order to obtain a catalyst with Rh and Mo contents similar to those present in the $\mathrm{RhMo}_{6} / \mathrm{G}$ catalyst. (ii) Monometallic $\mathrm{Rh} / \mathrm{G}$ and $\mathrm{Mo} / \mathrm{G}$ catalysts prepared by a conventional impregnation procedure, using $\mathrm{RhCl}_{3}$ and HMA aqueous solutions, respectively.

Before being used, all the catalysts were pretreated in $\mathrm{H}_{2}$ flow at $350{ }^{\circ} \mathrm{C}$.

\subsection{Characterisation of the Anderson Phase} and of the Prepared Catalysts

The textural properties of the supports were determined from the $\mathrm{N}_{2}$ adsorption-desorption isotherms at $-196{ }^{\circ} \mathrm{C}$ in Micromeritics ASAP 2020 equipment. 
The specific surface area $\left(S_{\mathrm{BET}}\right)$ was determined by the Brunauer, Emmett and Teller (BET) method (Brunauer et al. 1985). The samples were pretreated under vacuum in two stages of $1 \mathrm{~h}$ at 100 and $300{ }^{\circ} \mathrm{C}$. The pore distribution was determined by the Barrett-JoynerHalenda (BJH) method (Barrett et al. 1951) from the analysis of the micropore isotherm by the $t$ test (Lippens and de Boer 1965) taking the curve of Harkins and Jura (1994); the total pore volume was determined by the rule of Gurvitsch (1914).

The Mo and Rh contents were determined by atomic absorption spectrometry (AAS-equipment Varian AA $240)$ on the initial $\left(C_{\mathrm{i}}\right)$ and final $\left(C_{\mathrm{f}}\right)$ solutions. The adsorbed concentrations of Mo and $\left(C_{\mathrm{a}}^{\mathrm{Mo}}\right.$ or $\left.C_{\mathrm{a}}{ }^{\mathrm{Rh}}\right)$ were calculated from experimental $C_{\mathrm{i}}$ and $C_{\mathrm{f}}$ data, taking into account the volume of the impregnated solution and the mass of the support $(\mathrm{m})$ according to the expression:

$C_{\mathrm{a}}=\left\{\frac{\left(C_{\mathrm{i}}-C_{\mathrm{f}}\right) V}{m}\right\} 100$

The temperature-programmed reduction (TPR) patterns were obtained in a flow system with a mixture of 10 vol. $\% \mathrm{H}_{2}$ and 90 vol. $\% \mathrm{~N}_{2}$ volume $\left(20 \mathrm{~cm}^{3} / \mathrm{min}\right)$, by heating from room temperature up $850{ }^{\circ} \mathrm{C}$ at $10^{\circ} / \mathrm{min}$ in a Quantasorb Jr. (Quantachrome) equipment.

Scanning electron microscopy (SEM) with EDS analysis was performed in a Microscope Philips SEM 505 with a dispersive energy system for microanalysis (EDAX 9100).

The XRD patterns were collected in a Philips PW-1390 equipment using a $\mathrm{Cu} \mathrm{K} \alpha$ radiation source $(\lambda=1.5406 \AA)$ with $40 \mathrm{kV}$ and $20 \mathrm{~mA}$. Nickel filter and scanning angles in the $2 \theta$ range between 5 and $60^{\circ}$ at a scanning rate of $2 \% \mathrm{~min}$ were used. Crystalline phases were identified using the Joint Committee on Powder Diffraction Standards (JCPDS) files (Joint Comité for Powder Diffraction Standards).

X-ray photoelectron spectroscopy (XPS) spectra were recorded on a SPECS multi-technique analysis instrument spectrometer equipped with a dual X-ray $\mathrm{Mg} / \mathrm{Al}$ source and a PHOIBOS 150 hemispherical analyser in the fixed analyser transmission (FAT) mode. The spectra were obtained with a pass energy of $30 \mathrm{eV}$ and an $\mathrm{Mg}$ anode operated at $200 \mathrm{~W}$. The pressure during the measurement was lower than $2 \times 10^{-8}$ mbar. The sample was placed on the sample holder of the instrument, reduced to $350{ }^{\circ} \mathrm{C}$ for $10 \mathrm{~min}$ in a $5 \% \mathrm{H}_{2}$ in Ar flow and evacuated to ultra-high vacuum for at least $2 \mathrm{~h}$ before the measurement. The $\mathrm{Rh}_{3 d}, \mathrm{Mo}_{3 d}, \mathrm{O}_{1 s}$ and $\mathrm{Al}_{2 p}$ regions were processed by a computer. Electron binding energies (BE) were referenced to the $C_{1 \mathrm{~s}}$ peak at $284.6 \mathrm{eV}$. The intensity ratio $I_{\mathrm{Me}} / I_{\mathrm{Al}}$ (for $\mathrm{Me}=\mathrm{Rh}$ or Mo) was obtained from peak area determination by integration of the appropriate peaks. To assess a quantitative relationship between the XPS peak intensity ratio and surface composition, the experimental results were corrected with the values predicted by Scofield's sensitivity factors (Wagner et al. 1981).

The FT-IR spectra of pure Anderson phase and of the prepared catalysts were obtained in the $400-4000 \mathrm{~cm}^{-1}$ wavenumber range using $\mathrm{KBr}$ pellets in a Thermo Bruker IFS 66 FT-IR spectrometer.

Raman spectra were collected on powder samples at room temperature in the back-scattering geometry with an in Via Renishaw spectrometer equipped with an aircooled CCD detector and a super-Notch filter. The emission line at $514.5 \mathrm{~nm}$ from an $\mathrm{Ar}^{+}$ion laser was focused on the sample under a Leica DLML microscope using a $\times 20$ objective. Five 20 -s accumulations were attained for each sample with an incident beam power of about $5 \mathrm{~mW}$. The spectral resolution was $2 \mathrm{~cm}^{-1}$, and the spectra were calibrated using the $520.5 \mathrm{~cm}^{-1}$ line of a silicon wafer.

\subsection{Catalytic Test}

The hydrogenation of $\mathrm{NO}_{3}{ }^{-}$was carried out in a semi-batch Pyrex reactor. In a typical run, the catalysts were previously reduced under a $\mathrm{H}_{2}$ flow at $350{ }^{\circ} \mathrm{C}$ for $2 \mathrm{~h}$ and loaded in the reactor that contained a $100 \mathrm{ppm} \mathrm{NO}_{3}{ }^{-}$solution in degassed distilled water. The experiment was carried out for $6 \mathrm{~h}$ at atmospheric pressure, $25{ }^{\circ} \mathrm{C}$, with a $400 \mathrm{~mL} \min ^{-1} \mathrm{H}_{2}$ flow. To monitor the reaction progress, $1 \mathrm{~mL}$ samples were taken periodically. The samples were filtered and then analysed in an ion chromatograph (Metrohm 790 Personal IC) to determine $\mathrm{NO}_{3}{ }^{-}$and $\mathrm{NO}_{2}{ }^{-}$concentrations. A solution of $\mathrm{NaHCO}_{3} 1.0 \mathrm{mM}$ and $\mathrm{Na}_{2} \mathrm{CO}_{3} 3.2 \mathrm{mM}$ was used as the mobile phase, and the flow rate was set at $7 \mathrm{~mL} / \mathrm{min}$. Ammonium ions were determined by UV-Vis spectrophotometry (UV-Vis Thermo Spectronic Helios Gamma), following a modified 
Berthelot method (Marchesini et al. 2010). The selectivity to $\mathrm{NO}_{2}^{-}\left(S_{\mathrm{NO}_{2}^{-}} \%\right), \mathrm{NH}_{4}^{+}\left(S_{\mathrm{NH}_{4}^{+}} \%\right)$ and
$\mathrm{N}_{2}\left(S_{N_{2}} \%\right)$ after 300 min $(t)$ of reaction was calculated with the following equations:

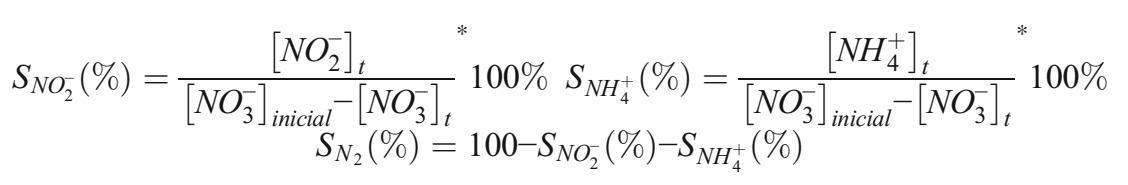

\section{Results and Discussion}

The term alumina is generally used to identify some of the crystalline forms of aluminium oxide $\left(\mathrm{Al}_{2} \mathrm{O}_{3}\right)$, aluminium hydroxide $\left(\mathrm{Al}(\mathrm{OH})_{3}\right)$ or aluminium hydroxide oxide (AlO $(\mathrm{OH})$ ) (Gitzen 1970). Aluminas occur in nature as hydroxides or hydrated mineral oxides (bauxite), which through hydrotreating processes are transformed into gibbsite or bayerite, which happen to be the precursors of the so-called transition aluminas. Among them, the most important is gibbsite, which is usually obtained through the Bayer process (Zhao and Chen 2003). In this process, bauxite ore is heated in a pressure vessel along with a sodium hydroxide solution at a temperature of 150 to $200{ }^{\circ} \mathrm{C}$, in order to obtain a sodium aluminate solution. After the separation of the insoluble impurities, the remaining solution is diluted with water in order to cause the hydrolysis and precipitation of gibbsite. Gibbsite is transformed into different types of aluminium hydrous oxides depending on the temperature and time of the process, and also on the treating atmosphere, giving rise to different crystalline phases along with the elimination of water. These so-obtained phases are called "transition aluminas", each one of them exhibiting characteristic properties: crystal structure, specific surface, grain size, etc. (Zhao and Chen 2003). In the present work, the sample thermally treated at $550{ }^{\circ} \mathrm{C}$ was selected to continue the rest of the experiments due to the fact that this support (designated as B) was the one with which the best textural characteristics (high $S_{\mathrm{BET}}$ and suitable pore size) were found.

The textural properties of the supports used in this paper are displayed in Table 1. Supports designated as G and A have textural properties corresponding to the traditional values found in the literature for these kinds of aluminas (Vieira Coelho et al. 2008). After the treatment at high $\mathrm{pH}$ with aqueous ammonia, the silica support (S) resulted in a solid with a high $S_{\mathrm{BET}}$ and high porosity compared with the untreated Aerosil Degussa $\left(65 \mathrm{~m}^{2} / \mathrm{g}\right.$ and $0.14 \mathrm{~cm}^{3} / \mathrm{g}$, respectively).

In Fig. 2, the $\mathrm{N}_{2}$ adsorption isotherms for $\mathrm{S}, \mathrm{G}$ and $\mathrm{B}$ supports are shown. These isotherms have been analysed in the light of the newest IUPAC Technical Report (Thommes et al. 2015). Taking into account these recommendations, physisorption isotherms of $\mathrm{G}$ and B supports correspond to Type IVa isotherms, typical of mesoporous adsorbents. The adsorption behaviour in mesopores is determined by the adsorbent-adsorbate interactions and also by the interactions between the molecules in the condensed state. In Type IVa isotherm, capillary condensation is accompanied by hysteresis. The observed hysteresis loops for $G$ and $B$ supports are of Type $\mathrm{H} 2$ and can be attributed either to pore-blocking/percolation in a narrow range of pore necks or to cavitation-induced evaporation (Thommes and Cychosz 2014).

Table 1 Nomenclature and textural properties of the supports

\begin{tabular}{llll}
\hline Support & Nomenclature & $S_{\text {BET }}\left(\mathrm{m}^{2} / \mathrm{g}\right)$ & Pore volume $\left(\mathrm{cm}^{3} / \mathrm{g}\right)$ \\
\hline$\gamma-\mathrm{Al}_{2} \mathrm{O}_{3}$ & $\mathrm{G}$ & 255 & 0.65 \\
$\mathrm{Al}(\mathrm{OH})_{3}$ calcined at $550{ }^{\circ} \mathrm{C}$ & $\mathrm{B}$ & 159 & 0.24 \\
$\alpha-\mathrm{Al}_{2} \mathrm{O}_{3}$ & $\mathrm{~A}$ & 10 & 0.05 \\
$\mathrm{SiO}_{2}$ & $\mathrm{~S}$ & 180 & 0.76 \\
\hline
\end{tabular}



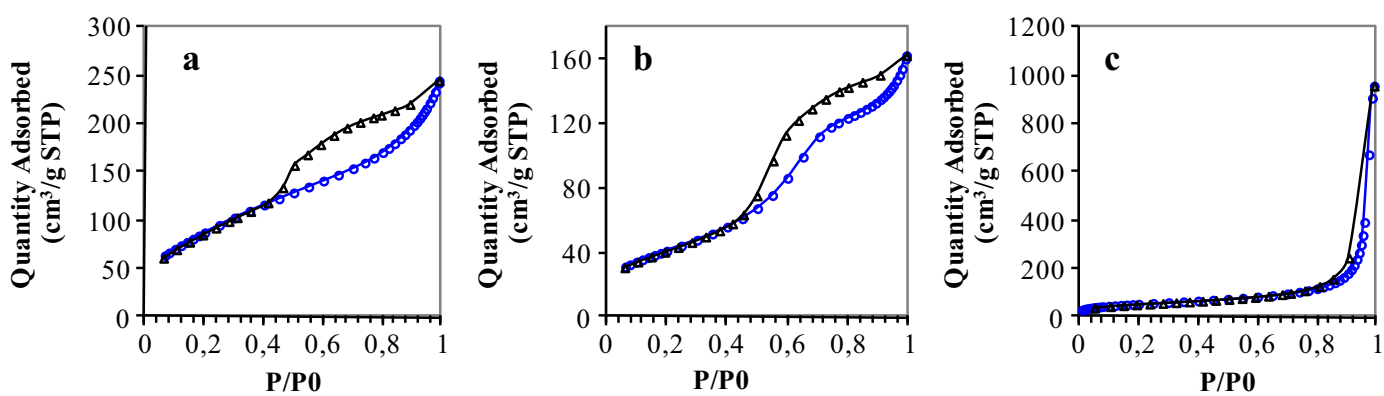

Fig. $2 \mathrm{~N}_{2}$ adsorption/desorption isotherms of $\mathrm{G}(\mathbf{a}), \mathrm{B}(\mathbf{b})$ and $\mathrm{S}(\mathbf{c})$ supports

On the other hand, the S support presents a Type V isotherm, typical of solids with a relatively weak adsorbent-adsorbate interaction. The observed hysteresis corresponding to a Type $\mathrm{H} 1$ loop is found in materials that exhibit a narrow range of uniform mesopores, as for instance in template silicas, some controlled pore glasses and ordered, mesoporous carbons. The steep, narrow loop characteristic of this type of hysteresis is assigned to a delayed condensation on the adsorption branch. However, Type H1 hysteresis has also been found in networks of ink-bottle pores where the width of the neck size distribution is similar to the width of the pore/cavity size distribution (Thommes and Cychosz 2014).

The X-ray diffraction patterns of $\mathrm{G}$ and $\mathrm{B}$ supports are depicted in Fig. 3(a, b). The diffraction signals for these supports at $2 \theta=15^{\circ}, 29.4^{\circ}, 39.0^{\circ}$ and $48.0^{\circ}$ (PDFWIN: 89-7717) account for the different degree of crystallinity of the solids. Figure 3(c) presents the XRD pattern of $\mathrm{S}$ support, which corresponds to an amorphous silica, as reported in the international database (PDFWIN: 38-0448).

The $\mathrm{RhMo}_{6}$ Anderson phase employed in this paper has been extensively characterised in previous work of our research group by different techniques including SEM-EDS, XRD, FT-IR and Raman microprobe. The main results of its characterisation can be summarised as follows: SEM-EDS microscopy showed that the synthesised crystals of $\left(\mathrm{NH}_{4}\right)_{3}\left[\mathrm{RhMo}_{6} \mathrm{O}_{24} \mathrm{H}_{6}\right] \cdot 7 \mathrm{H}_{2} \mathrm{O}$ (pale orange) were similar to other Anderson phases such as
$\mathrm{CoMo}_{6}, \mathrm{CrMo}_{6}$ and $\mathrm{AlMo}_{6}$. The XRD pattern of powder samples showed that the $\mathrm{Rh}$ phase was isomorphous to phases containing a trivalent metal as heteroatom. From the EDS semi-quantitative analysis, a good agreement was observed between the Rh and Mo contents obtained experimentally (15.91 wt\% and $84.09 \mathrm{wt} \%$ of $\mathrm{Rh}$ (III) and Mo (VI), respectively) and the theoretical values $15.16 \mathrm{wt} \%$ for $\mathrm{Rh}$ (III) and $84.83 \mathrm{wt} \%$ for Mo (VI) (Bertolini et al. 2013; Cabello et al. 2006).

In order to test the potentiality of $\mathrm{RhMo}_{6}$ phase in the catalytic denitrification of water, it was supported on the different selected solids, giving rise to $\mathrm{RhMo}_{6} / \mathrm{B}$, $\mathrm{RhMo}_{6} / \mathrm{G}, \mathrm{RhMo}_{6} / \mathrm{A}$ and $\mathrm{RhMo}_{6} / \mathrm{S}$ catalysts. The quantitative analysis of Rh and Mo was conducted by AAS, and the results are summarised in Table 2, together with the semi-quantitative EDS values.

Both alumina-supported catalysts $\left(\mathrm{RhMo}_{6} / \mathrm{B}\right.$ and $\left.\mathrm{RhMo}_{6} / \mathrm{G}\right)$ prepared by the equilibrium-adsorption method contained ca. $6 \mathrm{wt} \%$ Mo and $1.5 \mathrm{wt} \% \mathrm{Rh}$, in agreement with the previously prepared $\mathrm{RhMo}_{6}$-based supported catalysts (Bertolini et al. 2013). The concentration of $\mathrm{Rh}$ and Mo adsorbed on the support not only depends on the initial concentration of the starting solutions, but also on the interaction of the Anderson phase with the support. Thus, the similar octahedral coordination geometry of Rh (III) in the Anderson phase and of the $\mathrm{Al}$ (III) cations of the alumina support suggests an effective interaction of the $\mathrm{RhMo}_{6}$ phase with the alumina support, and a high affinity or possibility of

Fig. 3 XRD patterns of $\mathrm{G}$ (a); B (b) and S (c) supports
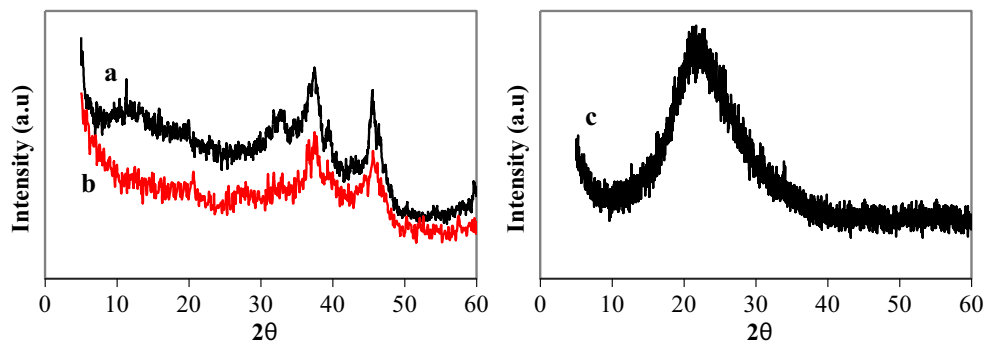
Table 2 Values for Rh and Mo concentration obtained by AAS and EDS semi-quantitative analysis

\begin{tabular}{lllll}
\hline Catalyst & \multicolumn{2}{l}{ Values obtained by AAS (\%) } & & \multicolumn{2}{c}{ Values obtained by EDAX (\%) } \\
\cline { 2 - 5 } & $\mathrm{Rh}$ & Mo & Rh & Mo \\
\hline $\mathrm{RhMo}_{6} / \mathrm{G}$ & 1.50 & 6.00 & 9.45 & 50.62 \\
$\mathrm{RhMo}_{6} / \mathrm{B}$ & 1.40 & 5.70 & 7.14 & 41.5 \\
$\mathrm{RhMo}_{6} / \mathrm{S}$ & 0.12 & 0.58 & 1.02 & 4.23 \\
\hline
\end{tabular}

exchange of $\mathrm{Rh}$ (III) and $\mathrm{Al}$ (III). The ionic radii of both cations in the octahedral coordination are similar $(0.53 \AA$ and $0.66 \AA$ for $\mathrm{Al}$ (III) and $\mathrm{Rh}$ (III), respectively) allowing a certain degree of substitution for one another on the support surface.

The values of Mo and $\mathrm{Rh}$ obtained for $\mathrm{RhMo}_{6} / \mathrm{S}$ were much lower: $0.58 \mathrm{wt} \%$ and $0.12 \mathrm{wt} \%$, respectively. However, the values found by the semi-quantitative method were $4.23 \%$ for Mo and $1.02 \%$ for Rh for the silica support. The lower adsorption of the Anderson phase on the silica support can be explained by the PI (isoelectric point) of the supports and the preferential impregnation of the heteropolyanion. The PI value for silica is 2 and indicates the acidic nature of the support, which means that at $\mathrm{pH}>2$ its surface mostly has negative charges; however, this becomes significant at $\mathrm{pH} \geq 5$. This is the $\mathrm{pH}$ value of the aqueous solution of the heteropolyanion of interest, in which this species is stable. So the impregnation of a polyanion such as $\left[\begin{array}{lll}\mathrm{RhMo}_{6} \mathrm{O}_{24} & \mathrm{H}_{6}\end{array}\right]^{-3}$ does not produce an effective exchange, as was demonstrated by the values obtained by the AAS and EDS methods. Also, Si (IV) has a ionic radius of $0.24 \AA$ in a tetrahedral environment, which does not favour its exchange with Rh (III), as in the case of alumina.

XRD patterns of the catalysts were obtained. The profile of the $\mathrm{RhMo}_{6} / \mathrm{G}$ catalyst shows the diffraction lines characteristic of the $\gamma-\mathrm{Al}_{2} \mathrm{O}_{3}$ support (PDFWIN: 89-7717). Unlike support $\mathrm{B}$, which presented the signals corresponding to $\gamma-\mathrm{Al}_{2} \mathrm{O}_{3}$, it showed a diagram with well-defined signals characteristic of boehmite when it was impregnated with the Anderson phase generating the $\mathrm{RhMo}_{6} / \mathrm{B}$ catalyst. According to Rinaldi et al. (2006), the hydration of a gamma alumina phase may result in the formation of aluminium oxyhydroxide and trihydroxide (boehmite and bayerite). So, it is possible to speculate that the impregnation in equilibrium of the support B with an aqueous solution of $\mathrm{RhMo}_{6}$ resulted in the hydration of the alumina, stabilising the boehmite phase. In both catalysts, structures containing neither Rh nor Mo were observed, suggesting a good dispersion or the presence of small metallic particles not detected by $\mathrm{XRD}$. The XRD analysis of the $\mathrm{RhMo}_{6} / \mathrm{S}$ catalyst did not show any peaks corresponding to $\mathrm{Rh}$ and/or Mo phases, in agreement with the low concentration of both metals deposited on the silica support.

Vibrational spectroscopy is a particularly useful technique for identifying the structure of the Anderson phases through the analysis of the vibrational modes of their typical bonds. Both the bulk Anderson phase and the $\mathrm{RhMo}_{6} / \mathrm{G}$ catalyst were analysed by FT-IR and Raman microprobe techniques. The FT-IR spectra of both samples are presented in Fig. 4(a, b). The main features typical of Anderson structure appear at $943\left(\nu_{\mathrm{s}}\right), 915 \mathrm{~cm}^{-1}$ and $887 \mathrm{~cm}^{-1}$ $\left(\nu_{\text {as }}\right)$ (Mo-Ot vibrations), $642 \mathrm{~cm}^{-1}$ (Mo-O bridge bonds) and $566 \mathrm{~cm}^{-1}$ (Rh-O stretching) (Cabello et al. 2002). For the $\mathrm{RhMo}_{6} / \mathrm{G}$ catalyst, the bands are less intense than those of the pure phase, but are still possible to observe them.

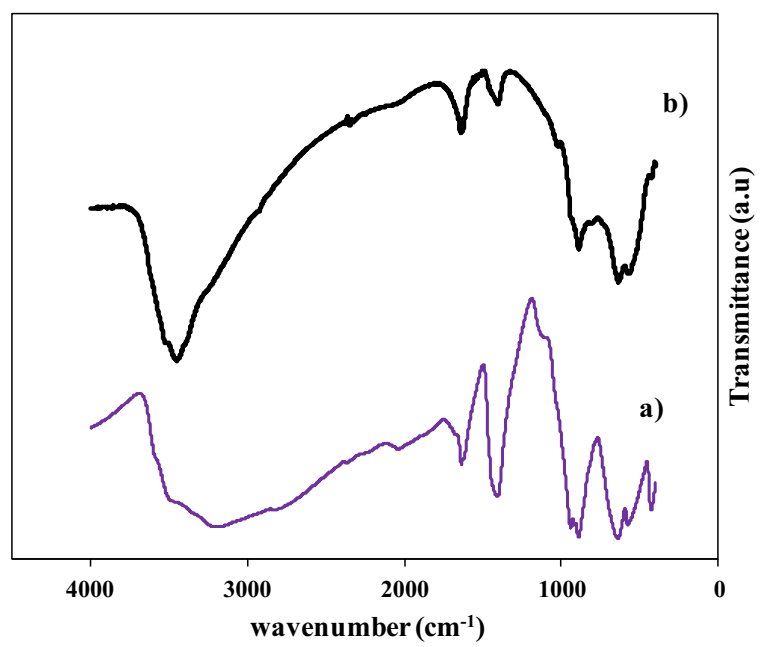

Fig. 4 FTIR spectra of $\mathrm{RhMo}_{6}$ (a) phase and $\mathrm{RhMo}_{6} / \mathrm{G}$ catalyst (b) 
Table 3 Binding energies (eV) and surface composition of the pure and supported $\mathrm{RhMo}_{6}$ phase

\begin{tabular}{lllll}
\hline Catalyst & $\mathrm{Rh}^{2} \mathrm{~d}_{5 / 2} / \mathrm{eV}$ & $\begin{array}{l}\text { Mo3d } \\
\mathrm{eV} / 2\end{array}$ & & \multicolumn{2}{l}{\begin{tabular}{l} 
Composition \\
\cline { 4 - 5 }
\end{tabular}} & & & $(\mathrm{nRh} / \mathrm{nMo})^{\mathrm{S}}$ & $(\mathrm{nRh} / \mathrm{nMo})^{\mathrm{A}}$ \\
\hline $\mathrm{RhMo}_{6}$ & 310.8 & 233.0 & 0.17 & 0.167 \\
$\mathrm{RhMo}_{6} / \mathrm{G}$ & 309.4 & 232.7 & 0.23 & 0.223 \\
$\mathrm{RhMo}_{6} / \mathrm{B}$ & 309.1 & 232.6 & 1.22 & 0.229 \\
\hline
\end{tabular}

${ }^{S}$ XPS-derived values

${ }^{\text {A }}$ Analytical data (phase $\mathrm{RhMo}_{6}$ for SEM/EDS, catalysts by AAS)

The Raman technique is especially interesting because it allows characterising alumina-supported Anderson phases more clearly than other techniques, showing the structure preservation. Using this technique, the preservation of the $\mathrm{RhMo}_{6}$ phase structure could be verified for the $\mathrm{RhMo}_{6} / \mathrm{G}$ catalyst. The same signals appear in the spectra of the pure and supported phases, with the sole difference that the main line corresponding to the symmetric stretching mode of the $\mathrm{Mo}-\mathrm{O}_{2 \mathrm{t}}$ terminal bonds presents a remarkable band broadening and a shift to lower frequencies as a result of its interaction with the support (Bertolini et al. 2013).

XPS analysis provides information on the chemical state and the degree of dispersion of surface species in the supported catalysts. The data of pure phase $\mathrm{RhMo}_{6}$ (Table 3) revealed signals of $\mathrm{Rh}_{3} \mathrm{~d}_{5 / 2}$ at $310.8 \mathrm{eV}$ and $\mathrm{Mo} \mathrm{d}_{5 / 2}$ at $233.0 \mathrm{eV}$, corresponding to Rh (III) and Mo
(VI), respectively. Due to the overlap of the $N_{1 \mathrm{~s}}$ band with the component $\mathrm{Mo} \mathrm{p}_{3 / 2}$, the status and the amount of $\mathrm{N}$ could not be determined. The chemical composition of the surface, $\mathrm{nRh} / \mathrm{nMo}=0.17$, derived from the $\mathrm{Rh} / \mathrm{Mo}$ intensity ratio, is in excellent agreement with the composition of the bulk, $\mathrm{nRh} / \mathrm{nMo}=0.167$ (Bertolini et al. 2013).

The $\mathrm{RhMo}_{6} / \mathrm{G}$ and $\mathrm{RhMo}_{6} / \mathrm{B}$ systems showed a shift towards lower binding energy (BE) values. In the catalyst with the best catalytic performance, $\mathrm{RhMo}_{6} / \mathrm{G}$, a $1.4 \mathrm{eV}$ shift towards lower values of the $\mathrm{Rh} 3 \mathrm{~d}_{5 / 2}$ binding energy is observed (Fig. 5a), indicating that $\mathrm{Rh}$ is in a metallic state (García-Fierro et al. 1988, Nyholm R., Martensson N. J. Phys. C. 13, L279 (1980)). The Mo 3d $\mathrm{d}_{5 / 2}$ band of the catalysts also showed a slight shift to lower BE values when compared to the pure Anderson phase, suggesting the presence of $\mathrm{MoO}_{\mathrm{x}}$ species with lower oxidation states $(2<x<3)$ (Fig. 5b) (Kim et al. 1974).

As to the surface composition, in the $\mathrm{RhMo}_{6} / \mathrm{G}$ catalyst, the $\mathrm{Rh} /$ Mo ratio was very similar to that obtained by AAS, revealing that the $\mathrm{Rh} / \mathrm{Mo}$ ratio in the deposited phase did not change. The $\mathrm{RhMo}_{6} / \mathrm{B}$ catalyst showed surface enrichment in $\mathrm{Rh}$, indicating that the $\mathrm{Rh}$ environment changed in one of the preparation steps.

TPR is an interesting method to analyse the heteropolyanion $\mathrm{RhMo}_{6}$-support interaction and the influence of the heteroatom $\mathrm{Rh}$ on the reducibility of Mo. The diagrams for HMA, the $\mathrm{RhMo}_{6}$ pure phase, the catalysts $\mathrm{RhMo}_{6} / \mathrm{G}, \mathrm{RhMo}_{6} / \mathrm{B}, \mathrm{RhMo}_{6} / \mathrm{S}$ and the catalyst prepared by successive impregnations $(\mathrm{RhMo} / \mathrm{G})$ are shown in Fig. 6. a)

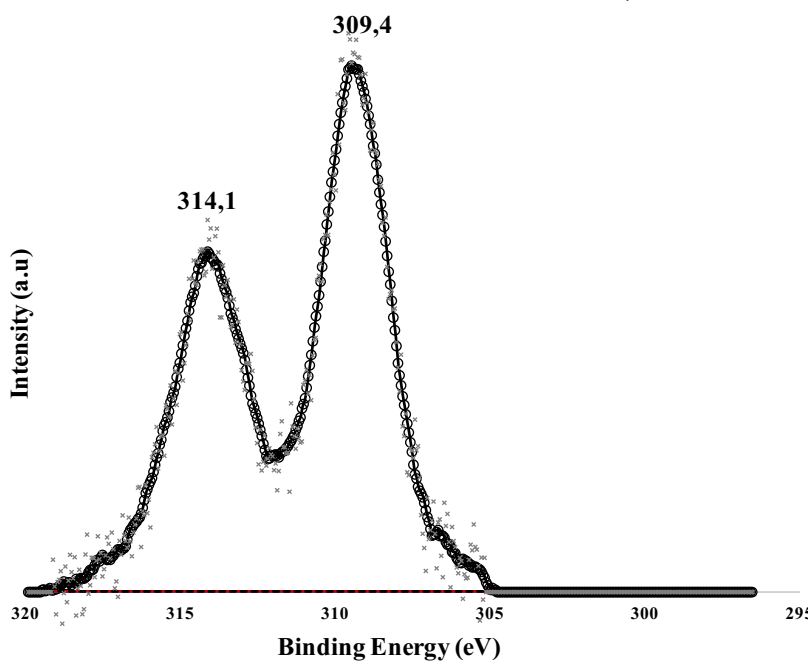

Fig. 5 XPS spectra of $\mathrm{RhMo}_{6}$ phase (a) and $\mathrm{RhMo}_{6} / \mathrm{G}$ catalyst (b)

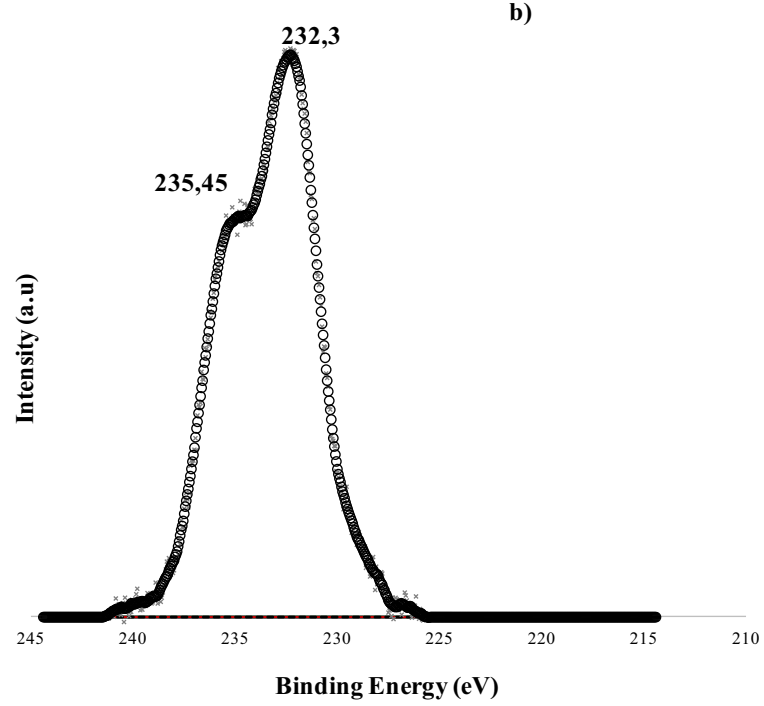




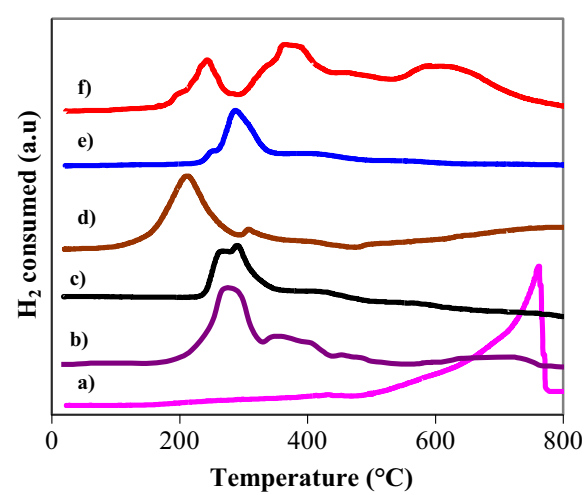

Fig. 6 TPR profile for HMA (a), $\mathrm{RhMo}_{6}$ pure Anderson phase (b), $\mathrm{RhMo}_{6} / \mathrm{B}$ (c), $\mathrm{RhMo}_{6} / \mathrm{G}$ (d), $\mathrm{RhMo}_{6} / \mathrm{S}$ (e) and $\mathrm{RhMo} / \mathrm{G}$ (f) catalysts

In an $\mathrm{H}_{2}$ reducing atmosphere, at elevated temperatures, Mo (VI) undergoes a complex process of reduction that is influenced by the metallic environment, the crystal structure of the original phase, the partially reduced phase and the presence of an additional metal in the structure (Cabello et al. 1994). The TPR profile for HMA was added for comparative purposes. There is a very low intensity peak at approximately $430{ }^{\circ} \mathrm{C}$ and another intense peak at approximately $760{ }^{\circ} \mathrm{C}$, corresponding to two reduction stages: (Mo (VI) $\rightarrow$ Mo $(\mathrm{IV}) \rightarrow \mathrm{Mo}^{\circ}$ ) respectively. For the $\mathrm{RhMo}_{6}$ phase, the TPR diagram presents a very intense signal at $285^{\circ} \mathrm{C}$, several signals of low intensity between 390 and $500^{\circ} \mathrm{C}$ and another at $730{ }^{\circ} \mathrm{C}$. The first peak at $285{ }^{\circ} \mathrm{C}$ is attributed to the reduction of $\mathrm{Rh}$ (III) $\rightarrow \mathrm{Rh}^{\circ}$. If it is considered that the reduction of $\mathrm{Rh}_{2} \mathrm{O}_{3}$ occurs at $135{ }^{\circ} \mathrm{C}$ (Bouras 2003), this effect can be assigned to greater stability in the condensed metal structure. The other signals correspond to the reduction of Mo, which occurs at temperatures below those observed for the reduction of HMA. This behaviour is attributed to the

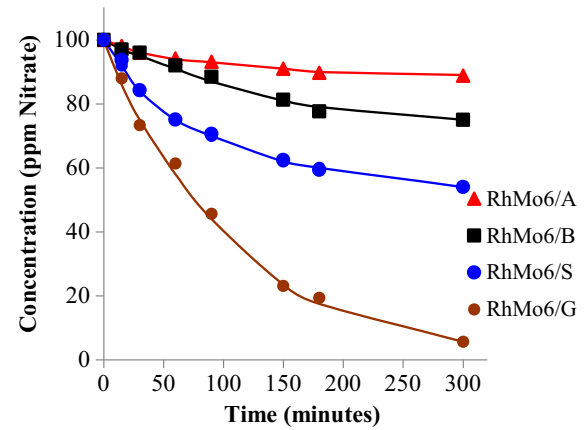

Fig. 7 Concentration of $\mathrm{NO}_{3}{ }^{-}$as a function of time for the catalysts containing the $\mathrm{RhMo}_{6}$ phase synergistic effect that exists in the Anderson phase, which could also be verified through the TPR of other Anderson phases (Cabello et al. 1994).

The $\mathrm{RhMo}_{6} / \mathrm{G}$ catalyst displayed $\mathrm{H}_{2}$ consumption peaks at $210^{\circ} \mathrm{C}$ and $310^{\circ} \mathrm{C}$, and showed a broad signal approximately at $730{ }^{\circ} \mathrm{C}$, while the $\mathrm{RhMo}_{6} / \mathrm{B}$ catalyst showed a broad $\mathrm{H}_{2}$ consumption peak in the range $210{ }^{\circ} \mathrm{C}-350{ }^{\circ} \mathrm{C}$, with a very similar profile to that of the $\mathrm{RhMo}_{6}$ pure phase. For the $\mathrm{RhMo}_{6} / \mathrm{S}$ catalyst, a strong signal around $290{ }^{\circ} \mathrm{C}$ was observed. Previous XRD and SEM-EDX characterizations of the pure phase treated at the main peak temperature revealed the simultaneous presence of $\mathrm{Rh}^{\circ}$ and different Mo phases $\left(\mathrm{Mo}^{\circ}\right.$ and $\left.\mathrm{MoO}_{2}\right)($ Cabello et al. 2002). The strong initial hydrogen consumption for the catalysts analysed involves not only the reduction of $\mathrm{Rh}$ (III) to $\mathrm{Rh}^{0}$ but also the partial reduction of Mo, which normally occurs at temperature close to $700{ }^{\circ} \mathrm{C}$ for a species such as ammonium heptamolybdate. This behaviour implies a promoter effect of $\mathrm{Rh}$ on Mo reducibility, as has recently been reported (Bertolini et al. 2013). In that, it was found that the high reducibility of $\mathrm{RhMo}_{6}$ can be associated with the oxidising character of the heteroatom $\left(\mathrm{E}^{\circ} \mathrm{Rh}(\mathrm{III})-\mathrm{Rh}^{\circ}=0.44 \mathrm{~V}\right)$ that promotes the activation of $\mathrm{H}_{2}$, which in turn affects the stability of Mo (VI), whose reduction begins at lower temperature.

The catalysts prepared using the $\mathrm{RhMo}_{6}$ phase were evaluated in the reaction of $\mathrm{NO}_{3}{ }^{-}$removal from water using $\mathrm{H}_{2}$ as a reducing agent. Figure 7 shows that all catalysts containing the $\mathrm{RhMo}_{6}$ phase were active in the removal of $\mathrm{NO}_{3}{ }^{-}$. The order of decreasing activity was the following: $\mathrm{RhMo}_{6} / \mathrm{G}>\mathrm{RhMo}_{6} / \mathrm{S}>\mathrm{RhMo}_{6} / \mathrm{B}>$ $\mathrm{RhMo}_{6} / \mathrm{A}$. In all the catalysts tested, the $\mathrm{pH}$ increase from 5.5 to 10 . The selectivity to $\mathrm{N}_{2}$ (Table 4) was higher than $90 \%$ in the three catalysts supported on alumina $\left(\mathrm{RhMo}_{6} / \mathrm{G}, \mathrm{RhMo}_{6} / \mathrm{B}, \mathrm{RhMo}_{6} / \mathrm{A}\right)$. For the catalyst supported on $\mathrm{SiO}_{2}$, the selectivity was low, around

Table 4 Concentration and selectivity to the products at the end of the reaction*

\begin{tabular}{llclcll}
\hline Catalyst & $\begin{array}{l}\text { Final } \\
\mathrm{ppm} \\
\mathrm{NO}_{3}^{-}\end{array}$ & $\begin{array}{l}\text { Final } \\
\mathrm{ppm} \\
\mathrm{NO}_{2}^{-}\end{array}$ & $\begin{array}{l}\text { Final } \\
\mathrm{ppm} \\
\mathrm{NH}_{4}^{+}\end{array}$ & $\begin{array}{l}\mathrm{S}_{\mathrm{NO}}^{-} \\
\%\end{array}$ & $\begin{array}{l}S_{\mathrm{NH}_{4}^{+}} \\
\%\end{array}$ & $\begin{array}{l}S_{\mathrm{N}_{2}} \\
\%\end{array}$ \\
\hline $\mathrm{RhMo}_{6} / \mathrm{A}$ & 89 & 0.8 & 0.04 & 7.3 & 0.36 & 92.3 \\
$\mathrm{RhMo}_{6} / \mathrm{S}$ & 54 & 16.5 & 0.20 & 36 & 0.43 & 63.6 \\
$\mathrm{RhMo}_{6} / \mathrm{B}$ & 75 & 2 & 0.16 & 8 & 0.64 & 91.4 \\
$\mathrm{RhMo}_{6} / \mathrm{G}$ & 6 & 1.2 & 0.09 & 1.3 & 0.10 & 98.6 \\
\hline
\end{tabular}

*The determinations were made at $300 \mathrm{~min}$ 


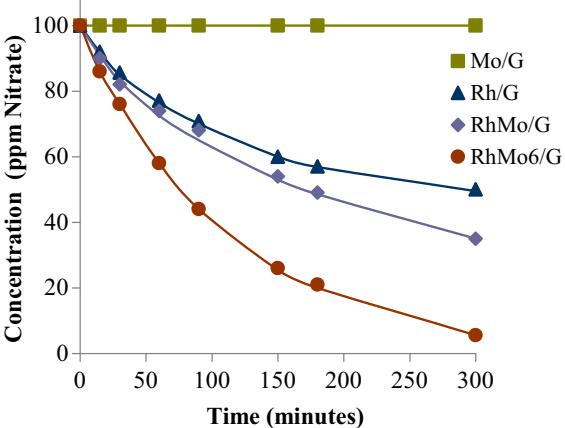

Fig. 8 Concentration of $\mathrm{NO}_{3}{ }^{-}$as a function of time for the monometallic and bimetallic catalysts containing $\mathrm{Rh}$ and $\mathrm{Mo}$

$64 \%$, compared to that of the alumina-based materials. For all the catalysts, the concentration of $\mathrm{NH}_{4}{ }^{+}$was below the limit values set by the European Community $(0.5 \mathrm{ppm})$. In addition, a rapid and substantial $\mathrm{pH}$ increase from the beginning of the reaction was observed for all the analysed catalysts.

As aforementioned, the characterisation of the supports and catalysts showed differences in the textural characteristics with the consequent different adsorption of the Anderson phase. Thus, for the $\mathrm{RhMo}_{6} / \mathrm{A}$ catalyst, the activity was low because of its low $S_{\mathrm{BET}}$ and pore volume that inhibit the effective adsorption of the heteropolyanion.

The study using transition aluminas of different textural properties (supports G and B) showed that these properties had a significant influence on the adsorption of the active phase and then on the catalytic performance. The $\mathrm{RhMo}_{6} / \mathrm{G}$ catalyst showed high catalytic activity, with only $6 \mathrm{ppm}$ of $\mathrm{NO}_{3}{ }^{-}$remaining at the end of the reaction (300 min), while for the system $\mathrm{RhMo}_{6} / \mathrm{B}$, at the same time, $75 \mathrm{ppm}$ of $\mathrm{NO}_{3}{ }^{-}$remained unconverted.

In the $\mathrm{RhMo}_{6} / \mathrm{B}$ catalyst, XPS results revealed a change in the Rh-Mo surface ratio and $\mathrm{Rh}$ surface enrichment. Thus, on partially losing their Mo environment, $\mathrm{Rh}$ atoms would act as a monometallic catalyst, i.e., with lower activity and higher selectivity to $\mathrm{NO}_{2}{ }^{-}$and $\mathrm{NH}_{4}{ }^{+}$than the $\mathrm{RhMo}_{6} / \mathrm{G}$ catalyst.

Finally, the $\mathrm{RhMo}_{6} / \mathrm{S}$ catalyst showed low capacity to eliminate $\mathrm{NO}_{3}{ }^{-}$and low selectivity to $\mathrm{N}_{2}$, compared to the $\mathrm{RhMo}_{6} / \mathrm{G}$ catalyst. Considering that the IP values of $\mathrm{G}$ and $\mathrm{S}$ supports are different, the $\mathrm{NO}_{3}{ }^{-}$removal rate was expected to be different as well. Working at a controlled $\mathrm{pH}$ of 5.5, Marchesini et al. (2008) found that the $\mathrm{NO}_{3}{ }^{-}$removal rate was higher for the $\mathrm{Al}_{2} \mathrm{O}_{3}$ support. This research group attributed the lower activity of the $\mathrm{SiO}_{2}$ support in $\mathrm{NO}_{3}{ }^{-}$removal to its lower IP value (3.2) compared to that of $\mathrm{Al}_{2} \mathrm{O}_{3}$ (7.7), which would decrease the adsorption efficiency of $\mathrm{NO}_{3}{ }^{-}$ions on the support.

The results obtained for the activity and selectivity towards $\mathrm{N}_{2}$ (Fig. 7 and Table 4) show that the catalyst with the best catalytic performance was $\mathrm{RhMo}_{6} / \mathrm{G}$. With the purpose of analysing whether the catalytic activity is favoured by the Anderson phase, a $\mathrm{RhMo} / \mathrm{G}$ catalyst was prepared for comparison purposes by the method of successive impregnation, as was described in the experimental section. In addition, the monometallic $\mathrm{Rh} / \mathrm{G}$ and $\mathrm{Mo} / \mathrm{G}$ catalysts were evaluated in the studied reaction.

The results for the removal of $\mathrm{NO}_{3}{ }^{-}$from water using the catalysts containing Rh and Mo are shown in Fig. 8. The $\mathrm{Mo} / \mathrm{G}$ catalyst is practically inactive in the removal of $\mathrm{NO}_{3}{ }^{-}$. Contrary to what was reported in the literature for monometallic catalysts prepared over an inert support such as $\gamma-\mathrm{Al}_{2} \mathrm{O}_{3}$, the $\mathrm{Rh} / \mathrm{G}$ catalyst is active in removing $\mathrm{NO}_{3}{ }^{-}$(Jaworski et al. 2013). In addition, this catalyst has a good selectivity towards $\mathrm{N}_{2}$ but greater selectivity towards $\mathrm{NO}_{2}^{-}$(Table 5) than the other catalysts tested. Probably the high hydrogenating capacity of $\mathrm{Rh}$ favours the reduction of $\mathrm{NO}_{3}{ }^{-}$.

Regarding the behaviour of bimetallic catalysts, when the RhMo/G system (prepared by successive impregnations) was used, the activity for the elimination of $\mathrm{NO}_{3}{ }^{-}$was lower than that of the $\mathrm{RhMo}_{6} / \mathrm{G}$ catalyst. The

Table 5 Concentration and selectivity to the products at the end of the reaction*

\begin{tabular}{|c|c|c|c|c|c|c|}
\hline Catalyst & Final ppm $\mathrm{NO}_{3}^{-}$ & Final ppm $\mathrm{NO}_{2}^{-}$ & Final ppm $\mathrm{NH}_{4}^{+}$ & $S_{\mathrm{NO}_{2}^{-}} \%$ & $S_{N H_{4}^{+}} \%$ & $S_{N_{2}} \%$ \\
\hline $\mathrm{Rh} / \mathrm{G}$ & 50 & 1.7 & 0.15 & 3.5 & 0.3 & 96.2 \\
\hline $\mathrm{Mo} / \mathrm{G}$ & 100 & - & - & - & - & - \\
\hline $\mathrm{RhMo} / \mathrm{G}$ & 35 & 1.2 & 0.78 & 1.9 & 1.2 & 96.9 \\
\hline RhMo6/G & 6 & 1.2 & 0.09 & 1.3 & 0.1 & 98.6 \\
\hline
\end{tabular}

*The determinations were made at $300 \mathrm{~min}$ 
selectivity to $\mathrm{N}_{2}$ after $300 \mathrm{~min}$ of reaction for both bimetallic catalysts is listed in Table 5. Besides being more active, the $\mathrm{RhMo}_{6} / \mathrm{G}$ catalyst gave a selectivity to $\mathrm{N}_{2}$ higher than $98 \%$, with a very low selectivity to $\mathrm{NO}_{2}{ }^{-}$ and $\mathrm{NH}_{4}{ }^{+}$, showing that the Anderson phase is a more effective precursor for bimetallic catalysts.

\section{Conclusions}

Bimetallic $\mathrm{RhMo}_{6}$ catalysts based on the adsorption of the Anderson-type planar heteropolymolybdate $\left[\mathrm{RhMo}_{6} \mathrm{O}_{24} \mathrm{H}_{6}\right]^{3-}$ on alumina and silica-based supports were prepared, characterised and evaluated in the reaction leading to $\mathrm{NO}_{3}{ }^{-}$removal.

All the catalysts containing the $\mathrm{RhMo}_{6}$ Anderson phase were active in the $\mathrm{NO}_{3}{ }^{-}$elimination in water. The $\mathrm{RhMo}_{6} / \mathrm{G}$ catalyst (supported on $\gamma$-alumina) showed the best $\mathrm{NO}_{3}{ }^{-}$activity (94\%) and selectivity to $\mathrm{N}_{2}$, while for the $\mathrm{RhMo}_{6} / \mathrm{B}$ catalyst (supported on boehmite-type alumina), the conversion was low (25\%) with a behaviour similar to that of the monometallic $\mathrm{Rh} / \mathrm{G}$ catalyst.

The catalytic performance (activity and selectivity to $\mathrm{N}_{2}$ ) of all the systems studied depends on the concentration of adsorbed $\mathrm{Rh}$ and on the $\mathrm{Rh} / \mathrm{Mo}$ surface ratio, which do not depend on the initial concentration of the starting solution but on the type of Anderson phasesupport interaction.

The XPS and TPR analyses showed that the RhMo $/$ $\mathrm{G}$ catalyst had a Rh/Mo surface ratio similar to that of the Anderson phase, indicating that this phase retained its structure up to the final stage of the preparation. $\mathrm{RhMo}_{6} / \mathrm{B}$ showed a surface enrichment in Rh, indicating that in this case the structure of the Anderson phase was at least partially destroyed during the preparation.

The lower activity and selectivity to $\mathrm{N}_{2}$ of a conventional $\mathrm{RhMo} / \mathrm{G}$ catalyst prepared by the successive impregnation of $\mathrm{Rh}$ and Mo salts confirms that the heteropolyanion-support interaction generates an active surface with an ordered and uniform distribution of $\mathrm{Rh}$ and Mo on the support, causing a synergistic effect that favours the catalytic activity.

The results obtained indicate that Anderson-type heteropolyanion-based systems can be applied to aqueous phase hydrogenation reactions, particularly in the elimination of $\mathrm{NO}_{3}{ }^{-}$in water for human consumption. In addition, the use of these systems allow to obtain catalysts with a reproducible $\mathrm{Rh} / \mathrm{Mo}$ ratio and a uniform active sites distribution.
Acknowledgements We are grateful to Mrs. Graciela Valle, Eng. Edgardo Soto, Lic. Mariela Theiller, Dra. Laura Barbelli and Eng. Hernán Bideberripe for their contribution and technical support.

Funding Information This study received financial support from the following institutions: CONICET (PIP 0276 and 0003), ANPCyT (PICT 0409) and UNLP (Subsidio Jóvenes Investigadores, Subsidio de Viajes) and Projects I172, X633 y X700; and CICPBA (Project 832/14).

\section{References}

Bae, S., Jung, J., \& Lee, W. (2013). The effect of pH and zwitterionic buffers on catalytic nitrate reduction by $\mathrm{TiO}_{2}$-supported bimetallic catalyst. Chemical Engineering Journal, 232, 327-337. https://doi.org/10.1016/j.cej.2013.07.099.

Barrabés, N., \& Sá, J. (2011). Catalytic nitrate removal from water, past, present and future perspectives. Applied Catalysis B: Environmental, 104, 1-5. https://doi.org/10.1016/j. apcatb.2011.03.011.

Barrett, E. P., Joyner, L. G., \& Halenda, P. P. (1951). The determination of pore volume and area distributions in porous substances. I. Computations from nitrogen isotherms. Journal of the American Ceramic Society, 73, 373-380.

Bertolini, G. R., Cabello, C. I., Muñoz, M., Casella, M., Gazzoli, D., Pettiti, I., \& Ferraris, G. (2013). Catalysts based on Rh (III)hexamolybdate $\gamma-\mathrm{Al}_{2} \mathrm{O}_{3}$ and their application in the selective hydrogenation of cinnamaldehyde to hydrocinnamaldehyde. Journal of Molecular Catalysis A: Chemical, 366, 109-115. https://doi.org/10.1016/j.molcata.2012.09.013.

Bertolini, G. R., Vetere, V., Gallo, M. A., Muñoz, M., Casella, M. L., Gambaro, L., \& Cabello, C. I. (2016). Composites based on modified clay assembled Rh (III)-heteropolymolybdates as catalysts in the liquid-phase hydrogenation of cinnamaldehyde. Comptes Rendus Chimie, 19(10), 1174 1183. https://doi.org/10.1016/j.crci.2015.09.015.

Bouras, O. (2003). Doctoral thesis, Université de Limoges, Faculté de Sciences et Techniques, Francia cap. 2.

Brunauer S, Emmett PH, Teller E (BET) method. (1985). In J. R. Anderson \& K. C. Pratt (Eds.), Introduction to characterization and testing of catalysts. Australia: Academic Press.

Cabello, C. I., Botto, I. L., \& Thomas, H. J. (1994). Reducibility and thermal behaviour of some Anderson phases. Thermochimica Acta, 232, 183-193. https://doi.org/10.1016 /0040-6031(94)80058-8.

Cabello, C. I., Botto, I. L., \& Thomas, H. J. (2000). Anderson type heteropolyoxomolybdates in catalysis: 1 . $\left(\mathrm{NH}_{4}\right)_{3}\left[\mathrm{CoMo}_{6} \mathrm{O}_{24} \mathrm{H}_{6}\right] \cdot 7 \mathrm{H}_{2} \mathrm{O} / \gamma-\mathrm{Al}_{2} \mathrm{O}_{3}$ as alternative of $\mathrm{Co}-\mathrm{Mo} /$ $\gamma-\mathrm{Al}_{2} \mathrm{O}_{3}$ hydrotreating catalysts. Applied Catalysis A: General, 197, 79-86. https://doi.org/10.1016/S0926-860X(99)00535-9.

Cabello, C. I., Botto, I. L., Muñoz, M., \& Thomas, H. (2002). Catalysts based on $\mathrm{RhMo}_{6}$ heteropolymetallates. Bulk and supported preparation and characterization. Studies in Surface Science and Catalysis, 143, 565-573.

Cabello, C. I., Muñoz, M., Botto, I. L., \& Payen, E. (2006). The role of $\mathrm{Rh}$ on a substituted $\mathrm{Al}$ Anderson heteropolymolybdate: thermal 
and hydrotreating catalytic behaviour. Thermochimia Acta., 447, 22-29.

Choi, E., Park, K., Lee, H., Cho, M., \& Ahn, S. (2013). Formic acid as an alternative reducing agent for the catalytic nitrate reduction in aqueous media. Journal of Environmental Sciences, 25, 1696-1702. https://doi.org/10.1016/S10010742(12)60226-5.

Citak, S., \& Sonmez, S. (2010). Effects of conventional and organic fertilization on spinach (Spinacea oleracea L.) growth, yield, vitamin $\mathrm{C}$ and nitrate concentration during two successive seasons. Scientia Horticulturae, 126, 415420. https://doi.org/10.1016/j.scienta.2010.08.010.

Costa, A. O., Ferreira, L. S., Passos, F. B., Maia, M. P., \& Peixoto, F. C. (2012). Microkinetic modeling of the hydrogenation of nitrate in water on $\mathrm{Pd}-\mathrm{Sn} / \mathrm{Al}_{2} \mathrm{O}_{3}$ catalyst. Applied Catalysis A: General, 445-446, 26-34.

Dalmon, J. A., \& Martin, G. A. (1980). Hydrogenolysis of $\mathrm{C}_{2} \mathrm{H}_{6}$, $\mathrm{C}_{3} \mathrm{H}_{8}$ and $\mathrm{n}-\mathrm{C}_{4} \mathrm{H}_{10}$ over silica-supported nickel-copper catalysts. Journal of Catalysis, 66, 214-221. https://doi. org/10.1016/0021-9517(80)90023-8.

Ding, Y., Sun, W., Yang, W., \& Li, Q. (2017). Formic acid as the in-situ hydrogen source for catalytic reduction of nitrate in water by PdAg alloy nanoparticles supported on aminefunctionalized $\mathrm{SiO}_{2}$. Applied Catalysis B: Environmental, 203, 372-380. https://doi.org/10.1016/j.apcatb.2016.10.048.

Fierro, J. L. G., Palacios, J. M., \& Tomas, F. (1988). An analytical SEM and XPS study of platinum-rhodium gauzes used in high pressure ammonia burners. Surface and Interface Analysis, 13, 25-32. https://doi.org/10.1002/sia.740130107.

Gitzen, W. H. (Ed.). (1970). Alumina as a ceramic material (1st. ed.). Wiley-American Ceramic Society. https://doi. org/10.17226/9575.

Gurvitsch, L. (1914). Physicochemical attractive force. Russian Journal of Physical Chemistry, 47, 805-812.

Haber, F., Le Rossignol R. (1910). Production of ammonium, US Patent 971501.

Harkins, W. D., \& Jura, G. (1994). Surfaces of solids. XIII. A vapor adsorption method for the determination of the area of a solid without the assumption of a molecular area, and the areas occupied by nitrogen and other molecules on the surface of a solid. Journal of the American Ceramic Society, 66, 1366-1376.

Jaworski, M. A., Vetere, V., Bideberripe, H. P., Siri, G., \& Casella, M. L. (2013). Structural aspects of $\mathrm{PtSn} / \gamma-\mathrm{Al}_{2} \mathrm{O}_{3}$ catalysts prepared through surface-controlled reactions: behavior in the water denitrification reaction. Applied Catalysis A: General, 453, 227-234. https://doi.org/10.1016/j. apcata.2012.12.034.

Kim, K. S., Baitinger, W. E., Amy, J. W., \& Winograd, N. (1974). ESCA studies of metal-oxygen surfaces using argon and oxygen ion-bombardment. Journal of Electron Spectroscopy and Related Phenomena, 5, 351-367. https://doi.org/10.1016/0368-2048(74)85023-1.

Kim, Y.-N., Yeob Kim, M., \& Choi, M. (2016). Synergistic integration of catalysis and ion-exchange for highly selective reduction of nitrate into $\mathrm{N}_{2}$. Chemical Engineering Journal, 289, 423-432. https://doi.org/10.1016/j.cej.2016.01.002.

Lippens, B. J., \& de Boer, J. H. (1965). Studies on pore systems in catalysts: V. The t method. Journal of Catalysis, 4, 319-323. https://doi.org/10.1016/0021-9517(65)90307-6.
Marchesini, F. A., Irusta, S., Querini, C., \& Miró, E. (2008). Nitrate hydrogenation over $\mathrm{Pt}, \mathrm{In} / \mathrm{Al}_{2} \mathrm{O}_{3}$ and $\mathrm{Pt}$, In/ $/ \mathrm{SiO}_{2}$. Effect of aqueous media and catalyst surface properties upon the catalytic activity. Catalysis Communications, 9, 10211026. https://doi.org/10.1016/j.catcom.2007.09.037.

Marchesini, F. A., Gutierrez, L. B., Querini, C. A., \& Miró, E. E. (2010). Pt,In and Pd, In catalysts for the hydrogenation of nitrates and nitrites in water. FTIR characterization and reaction studies. Chemical Engineering Journal, 159, 203-211. https://doi.org/10.1016/j.cej.2010.02.056.

Mizuno, N., \& Misono, M. (1998). Heterogeneous catalysis. Chemical Reviews, 98, 199-218. https://doi.org/10.1021 /cr960401q.

Pettiti, I., Botto, I. L., Cabello, C. I., Colonna, S., Faticanti, M., Minelli, G., Porta, P., \& Thomas, H. J. (2001). Anderson-type heteropolyoxomolybdates in catalysis: 2 . EXAFS study on $\gamma-\mathrm{Al}_{2} \mathrm{O}_{3}$-supported $\mathrm{Mo}$, Co and Ni sulfided phases as HDS catalysts. Applied Catalysis A: General, 220, 113-121. https://doi.org/10.1016/S0926-860X(01)00707-4.

Rinaldi, R., Fred, F. Y., \& Schuchardt, U. (2006). Structural, morphological and acidic changes of nanocrystalline aluminas caused by a controlled humidity atmosphere. Applied Catalysis A: General, 315, 44-51. https://doi.org/10.1016/j. apcata.2006.08.032.

Soares, O., Órfão, J., Ruiz-Martínez, J., Silvestre-Albero, J., Sepúlveda-Escribano, A., \& Pereira, M. F. R. (2010). Pd$\mathrm{Cu} / \mathrm{AC}$ and $\mathrm{Pt}-\mathrm{Cu} / \mathrm{AC}$ catalysts for nitrate reduction with hydrogen: Influence of calcination and reduction temperatures. Chemical Engineering Journal, 165, 78-88.

Thommes, M., \& Cychosz, K. A. (2014). Physical adsorption characterization of nanoporous materials: progress and challenges. Adsorption, 20, 233-250. https://doi.org/10.1007 /s10450-014-9606-z.

Thommes, M., Kaneko, K., Neimark, A. V., Olivier, J. P., RodríguezReinoso, F., Rouquerol, J., \& Sing, K. S. W. (2015). Physisorption of gases, with special reference to the evaluation of surface area and pore size distribution (IUPAC Technical Report). Pure and Applied Chemistry, 87(9-10), 1051.

Vieira Coelho, A. C., Rocha, G. A., Souza Santos, P., Souza Santos, H., \& Kiyohara, P. K. (2008). Specific surface area and structures of aluminas from fibrillar pseudoboehmite. Revista Matéria, 13(2), 329.

Vorlop, K.-D., \& Tacke, T. (1989). Kinetic investigation of the catalytic nitrate reduction: construction of the test reactor system. Chemie Ingenieur Technik, 61, 836-837. https://doi.org/10.1002/cite.330611023.

Wagner, C. D., Davis, L. E., Zeller, M. V., Taylor, J. A., Raymond, R. H., \& Gale, L. H. (1981). Empirical atomic sensitivity factors for quantitative analysis by electron spectroscopy for chemical analysis. Surface and Interface Analysis, 3, 211225. https://doi.org/10.1002/sia.740030506.

Zhao, J., \& Chen, Q. (2003). Study on enhancement in gibbsite precipitation of Bayer process under $33 \mathrm{kHz}$ ultrasound. Journal of Materials Science and Technology, 19, 607-610.

Zoppas, F. M., Marchesini, F. A., Devard, A., Bernardes, A. M., \& Miró, E. E. (2016). Controlled deposition of $\mathrm{Pd}$ and In on carbon fibers by sequential electroless plating for the catalytic reduction of nitrate in water. Catalysis Communications, 78, 59-63. https://doi. org/10.1016/j.catcom.2016.02.012. 